\title{
MASJID RAYA SUMATRA BARAT SEBAGAI SIMBOL PERSATUAN MUSLIM DI SUMATRA BARAT
}

\author{
Nurhayatu Nufut Alimin \\ nurhayatunufutalimin@gmail.com
}

\begin{abstract}
Abstrak
Masjid Raya Sumatera Barat merupakan masjid terbesar di Sumatera Barat, Indonesia. Masjid ini dirancang oleh Tim Khusus yang dibentuk oleh pemerintah Sumatra Barat. Berbeda dari kebanyakan masjid lainnya, masjid ini memiliki bentuk yang unik yaitu dengan menggabungkan unsur-unsur dari rumah gadang, dan unsur modern, bentuk yang unik menimbulkan persepsi yang bermacam-macam dari masyarakatnya sendiri, baik positif maupun negatif. Dari persepsi yang bermacam-macam tersebut penulis mencoba menelusuri apa makna yang muncul dari bentuk bangunan masjid tersebut. Pencarian makna pada desain masjid ini dilakukan dengan menganalisis bentuk visual, tema, dan esensi di balik itu. Penelitian ini meneliti bagian interior masjid yang menjadi ikon pada bangunan ini yang meliputi arsitektur dan interior bangunannya. Berdasarkan penelitian yang dilakukan oleh penulis, masjid ini merupakan bangunan Neo-Vernakular, konsep yang diangkat adalah "Musyawarah dan Mufakat" yang dikenal sebagai filosofi masyarakat Minangkabau dalam mengambil keputusan. Melalui penelitian ini penulis menemukan bahwa masjid ini merupakan simbol pemersatu bagi umat Islam di Sumatera Barat. Hal tersebut dapat dilihat dari perkembangan budaya masyarakat setempat bahwa umat Islam di Sumatera Barat memiliki beberapa aliran dan beberapa cara pandang yang berbeda terhadap Islam. Dengan demikian, secara tidak langsung masjid ini diharapkan dapat memberikan dampak sosial dan psikologis yang mampu mewakili penyatuan umat Islam di Sumatera Barat.
\end{abstract}

Kata kunci : masjid raya Sumatra Barat, Islam, Minangkabau, ikonografi-ikonologis

\begin{abstract}
Masjid Raya Sumatra Barat is the largest mosque in West Sumatra, Indone-sia. This mosque was designed by Team elected based by the government of western Sumatra. Different from most other mosques, this mosque has a unique shape that is by incorporating elements of the rumah gadang and modern style. By the uniqe shape, thise mosque made many perception from people inWest Sumatra barat, even positif and negative. From that perception I want to find the meaning of that uniqe shape from arsitecture this mosque. Searching for the meaning on the design of this mosque was done by analyzing the visual form, theme, and the essence behind it. This study examines the parts of the interior of the mosque which became the icons on this building which includes acrhitecture and Interior. Based on research conducted by the author of this mosque is NeoVernacular buildings, theme pre- sented is compromise with icon word in Minangkabau is "musyawah and mufakat" that's mean is discussion to reach an agreement. Through the study found that this mosque is a unifying symbol for Muslims in West Sumatra - see the development of cultural community, Muslims in the West Sumatra has some of the cult and perspective about Islam. Thus indirectly the mosque is expected to provide social and psychological effects are capable of representing the unification of Muslims in West Sumatra.
\end{abstract}

Keywords : masjid raya Sumatra Barat, Islam, Minangkabau, iconography-iconology 


\section{Pendahuluan}

Belakangan ini masyarakat Indonesia cenderung lebih tertarik kepada hal-hal berbau modern seperti halnya teknologi canggih dengan desain yang lebih sederhana dan elegan dibandingkan dengan model tradisional. Hal ini berpengaruh juga terhadap bentuk bangunan yang ada di Sumatera Barat, dahulu bentuk rumah dan bangunan yang ada di Sumatera barat didominasi oleh bentuk-bentuk tradisional seperti Rumah Gadang, namun seiring berjalannya waktu, bentuk-bentuk tersebut ditinggalkan dan mulai beralih kepada bentuk-bentuk yang lebih modern dengan bahan yang lebih kokoh.

Bentuk-bentuk tradisional yang sudah lama ditinggalkan itu mulai menarik minat masyarakat Indonesia lagi, saat ini banyak yang ingin memodifikasi dan mengembangkan lagi gaya tradisional tersebut. Hal ini terjadi karena barangkali sudah banyak yang menyadari akan pentingnya identitas dari kebudayaan lokal. Namun para arsitek dan desainer tidak serta merta mengambil dan meletakkan kembali unsur tradisonal dan meninggalkan perkembangan zaman. Mereka melakukan penelitian dan mencoba mengupayakan kedua hal tersebut dengan menggabungkan unsur tradisional dan unsur modern di dalam suatu bangunan.

Salah satu bentuk penggabungan kedua unsur tersebut yang cukup fenomenal dan baru saja dibangun adalah Masjid Raya Sumatera Barat (MRSB) yang terletak di Jl. Khatib Sulaiman di Padang, Sumatera Barat. Bangunan ini sendiri sampai saat ini belum sepenuhnya rampung, ada beberapa bagian bangunan yang sudah selesai, namun sebagian lagi masih dalam proses sehingga agak menyulitkan untuk dilakukan penelitian. Maka dari itu penelitian ini akan lebih mengacu kepada hasil desain masjid tersebut.

Desain Bentuk masjid ini terbilang unik, berbeda dari kebanyakan masjid di Sumatera Barat lainnya yang bergaya modern lebih banyak menggunakan kubah sebagai bagian atap masjid dengan bahan utama bangunan yang terbuat dari beton. Sedangkan masjid dengan gaya tradisional banyak yang memakai bentuk Rumah Gadang dengan menaruh gonjong pada bagian atap masjid. Proses pengerjaannya menggunakan bahanbahan dan alat yang modern. Maka masjid ini tidak tergolong ke dalam kedua ciri masjid di atas.

Berawal dari bentuk yang tidak biasa tersebut, masjid ini menuai beberapa anggapan dari masyarakat sekitar terhadap masjid ini, mereka mengatakan bahwa bangunan ini tidak mencerminkan bentuk masjid dan meragukan keberadaannya. Bahkan dari beberapa keraguan tersebut sampai berhembus kabar tentang adanya bentuk ornamen masjid yang diklaim sebagai bentuk motif yang biasa dipakai orang Yahudi (Pentagram). Hal ini membuat penulis tertarik untuk mengkaji bentuk pola arsitektur dan interior yang dihadirkan pada masjid tersebut, serta makna dibalik bentuk yang yang digunakan pada masjid tersebut, maka dari itu penulis akan mengungkapnya secara mendalam pada penelitian kali ini. 


\section{Masjid}

Masjid sebagai bangunan merupakan tempat untuk melaksanakan ibadah kaum muslimin menurut arti yang seluas-luasnya. Sebagai bagian dari arsitektur, masjid merupakan konfigurasi dari segala kegiatan kaum muslimin dalam melaksanakan kegiatan agamanya. Dengan demikian maka masjid sebagai bangunan merupakan ruang yang berfungsi sebagai penampungan kegiatan pelaksanaan ajaran agama Islam sehingga terdapatlah kaitan erat antara seluruh kegiatan keagamaan dengan masjid (Rochym, 1995: 14).

Pertumbuhan masjid itu senantiasa mengikuti sifat perkembangan Islam yang memasuki perbagai kehidupan yang beraneka ragam sifatnya di setiap daerah perkembangannya. Oleh karena itu, maka masjid juga memberikan kesan yang akrab dengan segi-segi kehidupan social sebagai konsekuensi dari kehidupan yang sudah berdasarkan Islam tersebut (Rochym, 1995: 15).

Sehingga dapat disimpulkan bahwa masjid merupakan tempat untuk beribadah dan melaksanakan kegiatan positif umat Islam lainnya, semakin berkembang Islam di suatu lingkungan maka semakin banyak pengaruh yang masuk sehingga melahirkan bentukbentuk masjid yang beragam.

\section{Bagian-bagian Masjid}

Bangunan Masjid terdiri dari beberapa bagian yang menjadi ciri khas dari bangunan masjid, bagian-bagian tersebut dijelaskan dalam (Situmorang, 1988: 24) meliputi Mihrab (tempat Imam memimpin Sholat) Mimbar, Liwan (tempat makmum), Menara, kubah, pintu masuk, serambi, dan sahn (tempat berwudu). Dalam penelitian ini, bagian-bagian pada ruangan tersebut akan dibagi ke dalam dua kategori yang pertama yaitu bagian eksterior yang tampak pada bangunan arsitektur masjid secara keseluruhan termasuk kubah dan struktur bangunan dan yang kedua yaitu bagian interior masjid meliputi liwan, sahn dan bentuk bagian dalam masjid secara keseluruhan.

Bagian-bagian yang akan dikaji ini memiliki peran yang penting dan saling menunjang satu sama lain yang disusun sedemikian rupa untuk menghadirkan kenyamanan kepada pengguna ruangannya. Arsitektur dan interior pada dasarnya adalah satu kesatuan, sebagaimana yang dijelaskan oleh Pile, (1988:389) bahwa hubungan desain interior dengan Arsitektur begitu erat dan tidak terbantahkan. Sebuah bangunan dirancang mengikuti ruang dalam yang sejalan dengan bentuk tampilan eksteriornya (Rony, 2014: 123).

Islam masuk ke Minangkabau melalui dua jalur. Menurut Aswil Rony (2002: 11) Pertama melalui jalur Pesisir Timur (Selat Malaka) melalui Rantau Kuantan, Kampar, Siak dan Indragiri. Kedua dengan Pesisir Barat (Samudra India) melalui Bandar-bandar lama seperti Tiku dan Pariaman. Selanjutnya agama Islam dari Pesisir Timur (daerah rantau) dan daerah Pesisir Barat bertemu di daerah Minangkabau asli. Inilah mungkin yang dimaksud pepatah (syara' mendaki, adat menurun) yang artinya adat turun ke daerah rantau (Pesisir) dan syara' (hukum agama) mendaki ke darek (wilayah asal nenek moyang Minangkabau). 
Sudarman (2010) menjelaskan Sejak Islam datang dan menjadi agama mayoritas di Minangkabau, maka Islam yang datang itu tidak serta merta kemudian menghapus tradisi dan kebudayaan yang telah berkembang sebelumnya. Bahkan yang terjadi adalah adanya pengaruh Hal ini telah diakomodir dalam statement adat "balabuah batapian, babalai bamusajik".

Menurut Yulianto Sumalyo (2000:478) dalam Sudarman 2010, arsitektur masjid di Minangkabau bersifat vernacular artinya memakai bentuk-bentuk setempat (arsitektur tradisional) seperti masjid Taluak di Bukittinggi, terlihat jelas selain pada hiasannya, juga pada atapnya miring sangat tajam. Pada puncak atapnya yang piramidal empat tingkat (dalam bahasa Minangkabau yaitu barundak) dihias dengan miniatur rumah gadang, yaitu rumah adat Minangkabau dengan atap mejemuk runcing mencuat di ujungujungnya.

\section{Metode Penelitian}

Metode yang digunakan pada penelitian ini yaitu metode Kualitatif, adapun metode kualitatif menurut Klerk dan Muller merupakan pengamatan yang lebih menekankan pada segi kualitas secara alamiah karena menyangkut pengertian konsep, nilai, serta ciriciri yang melekat pada objek penelitian (Kaelan, 2005: 5).

Metode pengumpulan data yang digunakan pada penelitian ini yaitu studi kepustakaan dari berbagai literatur, buku bacaan, jurnal dan media internet, observasi ke lapangan dan wawancara.

Pendekatan pada oenelitian ini menggunakan teori Ikonografi-ikonologis, seperti yang dijelaskan oleh Erwin Panofsky tentang mengkaji ikon berdasarkan bentuk visual dengan didukung oleh fakta sejarah. Proses analisis ini menggunakan tiga tahapan yaitu tahapan praikonografi, analisis Ikonografi, dan interpretasi ikonologis.

Tiga pemaknaan karya seni ini diurai sebagai berikut : pertama, deskripsi Praikonografi yaitu menangkap pemaknaan pertama suatu karya seni dengan mengidentifikasi bentuk-bentuk yang masih murni seperti konfigurasi garis dan warna. Kedua, analisis ikonografis mempelajari pemaknaan dengan menggunakan aturan-aturan yang sudah disetujui oleh pakar seni, yang artinya menjelaskan pemaknaan karya seni dari sumber-sumber literatur, memfokuskan pada pemaknaan yang dikaitkan dengan dunia gambar, sejarah, dan alegori. Ketiga, interpretasi ikonologis adalah cara memahami karya seni melalui penetapan makna isinya dengan menyingkap prinsip-prinsip yang terkandung di dalamnya. Makna ini dikaitkan dengan bagian dari mentalitas dasar budaya yang memanifestasikan budaya yang lain (ilmu pengetahuan, agama, filsafat, ideologi).

\section{Deskripsi Pre-iconographical Bentuk Arsitektur (Eksterior Bangunan)}

Masjid Raya Sumatera Barat ini dibangun di lahan seluas sekitar 40.000 meter persegi dengan luas bangunan utama kurang dari setengah luas lahan tersebut, yakni sekitar 18.000 meter persegi, sehingga menyisakan halaman yang luas. Pada struktur konstruksi bangunan menunjukkan pola rumah gadang dengan pola segitiga ke bawah, bahan 
material kayu dan ornament pada passade masjid merupakan bentuk ukiran yang terdapat pada rumah gadang, gonjong yang dihadirkan berakar dari bentuk gonjong pada rumah gadang.

Bagian atap (kubah) pada masjid ini sangat ikonik, atap masjid ini terlihat seperti gonjong rumah gadang diikuti dengan bentuk ukiran kayu yang terdapat pada bagian dinding-dinding atap (Passade) yang mengambil bentuk ukiran pada rumah gadang. Jika diperhatikan lebih lanjut, atap dari masjid ini mengikuti bentuk pola rumah gadang yang berpola segitiga ke bawah dan kembang ke atas, yang artinya berpegangan ke pada bumi.

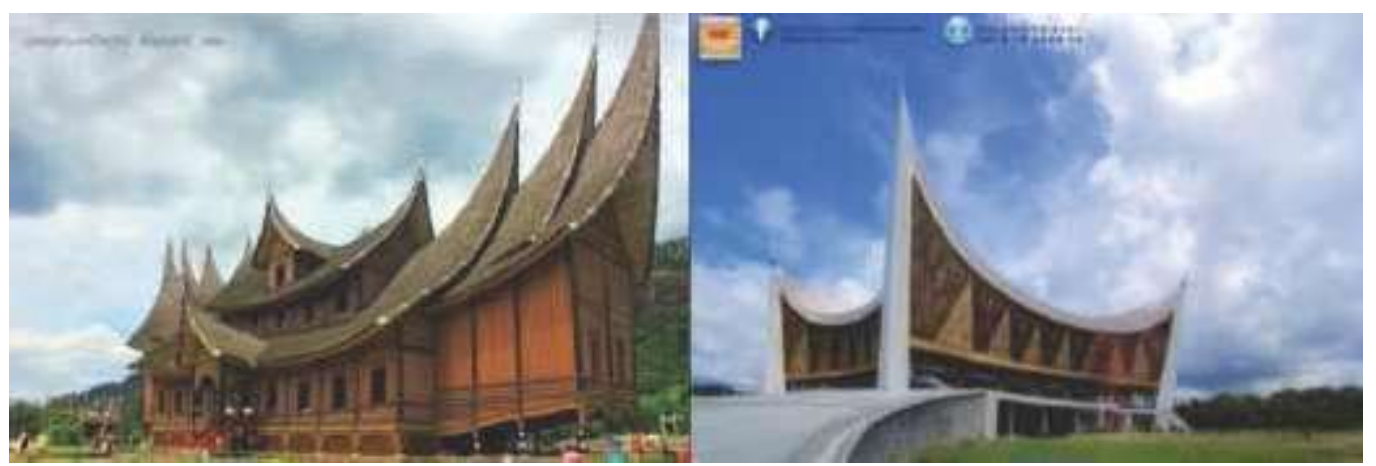

Gambar 1. Bangunan Rumah gadang sebelah kiri dan MRSB tampak luar (eksterior) sebelah kanan Sumber : Youtube sumber: Pungky Sudrajat

Lihatlah kedua pola bangunan di atas, bangunan rumah gadang melebar ke atas, begitu pula dengan MRSB, hal ini menunjukkan struktur bangunan yang sama, bentuk gonjong pada rumah gadang juga menunjukkan pola desain yang sama meskipun tidak persis sama dengan pola gonjong rumah gadang. Hal ini menunjukkan bahwa masjid ini tersinspirasi dari bentuk rumah gadang, kemudian memodifikasinya dengan bentuk yang lebih sederhana. Pola yang sama ini disebut segitiga terbalik atau orang Minang menyebutnya dengan mambasuik bumi.

\section{Bentuk Interior Bangunan}
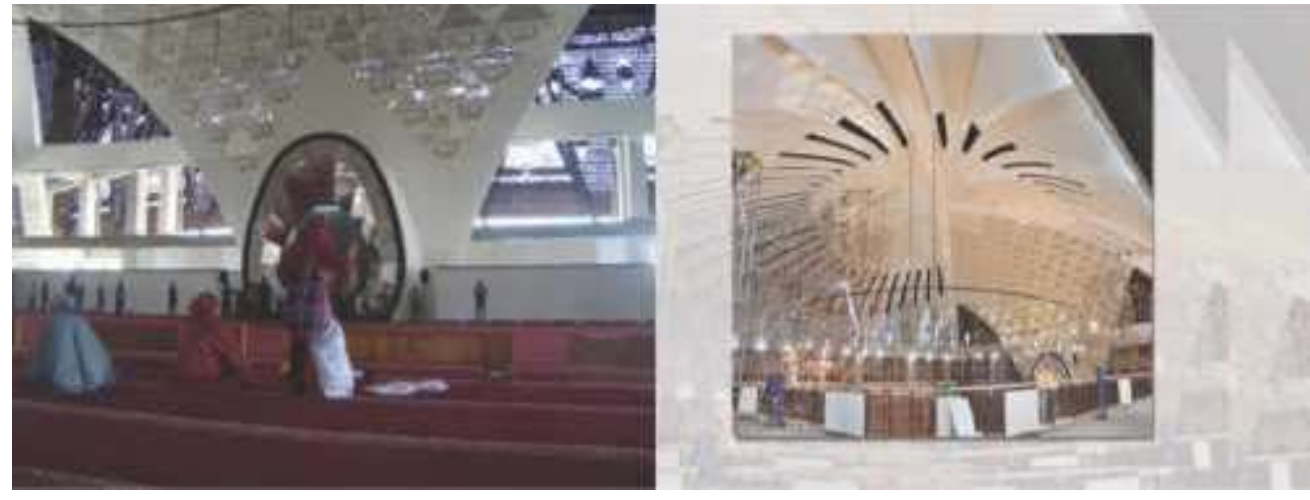

Gambar 2. Interior Masjid Raya Sumatera Barat dan video perkembangan interior MRSB Sumber: Youtube 
Pada bagian interior ini terdiri dari bagian Mihrab, Liwan dan Sahn. Pada bagian Mihrab ini mengusung bentuk desain yang lebih modern, bentuk lingkaran bulat telur itu mengingatkan penulis kepada karya rancangan desainer terkenal dunia yaitu Karim Rashid seorang desainer yang sangat terkenal dengan gaya futuristiknya, dia sering membuat bentuk-bentuk yang hampir serupa dengan rancangan mihrab masjid ini. Di lain sisi, bentuk mihrab seperti bulat telur juga mengingatkan kepada bentuk hajar aswad yang berada di makkah. Sedangkan bentuk Liwan pada masjid di desain sangat bersih dan kelihatan kokoh dengan menggunakan material beton dan keramik. Pada bagian dinding ruangan didominasi oleh pintu-pintu dan jendela yang memiliki lubang-lubang vertikal sebagai sirkulasi udara yang masuk dari luar ke dalam ruangan. Pada bagian plafonnya terdapat bentuk bagian dalam kubah yang langsung membungkus semua ruangan, meskipun tidak menampakkan bentuk kubah pada bagian luar, namun bentuk kubah dapat terlihat pada bagian dalam masjid. Plafon tersebut dipenuhi dengan tulisan kaligrafi Asmaul Husna (nama-nama Allah) dan pada bagian tengah liwan terdapat susunan lampu-lampu yang menggantung membentuk lingkaran pada bagian atas plafon ruangan, hal ini menunjukkan bentuk modern dan tidak terlihat bentuk tradisional dari dalam masjid ini.

Sahn atau tempat berwudu pada masjid ini di desain sangat sederhana dengan warna gelap. Tempat berwudu ini di desain terbuka sehingga membabawa udara yang masuk ke dalam sehingga menghasilkan hawa kesekukan. Tempat berwudu ini terbilang modern dan ramah lingkungan dengan terbukti dari sistim pemanfaatan air hujan yang digunakan.

Dari uraian di atas, dapat disimpulkan bahwa unsur yang kuat pada elemen-elemen interior yaitu didominasi oleh bentuk-bentuk yang unik, bersih dan licin. Selain itu sistim yang digunakan untuk menampung air sudah menggunakan teknologi menetralisir air hujan. Hal ini menunjukkan bahwa desain yang digunakan pada masjid ini sudah mengarah kepada sistem kecanggihan tekonologi dan ramah lingkungan, desain ini sangat populer akhir-akhir ini. Sedangkan pada bagian arsitektur masjid atau eksterior masjid didominasi oleh bentuk-bentuk tradisional seperti bentuk gonjong dan ukiran khas. Minangkabau yang terinspirasi dari motif kain songket Minangkabau pada kubah masjid.

Melihat dari hasil deskripsi masjid di atas, maka masjid ini dapat dikatakan masuk ke dalam golongan aliran arsitektur Neo Vernacular. Aliran Arsitektur Neo Vernakular ini merupakan akibat dari era post-modern sehingga memunculkan bentuk-bentuk dan gayagaya baru di dalam arsitektur. Arsitektur postmodern dan aliran-aliran lainnya merupakan arsitektur yang menggabungkan antara tradisional dengan non tradisional, modern dengan setengah nonmodern, perpaduan yang lama dengan yang baru. Sedangkan arsitektur vernacular berada pada posisi arsitektur modern awal dan berkembang menjadi Neo Vernakular pada masa modern akhir setelah terjadi eklektisme dan kritikan-kritikan terhadap arsitektur modern.

Neo berasal dari bahasa Yunani dan digunakan sebagai fonim yang berarti baru. Jadi, Neo-Vernacular berarti bahasa setempat yang di ucapkan dengan cara baru, arsitektur Neo-Vernacular adalah suatu penerapan elemen arsitektur yang telah ada, baik fisik (bentuk, konstruksi) maupun non fisik (konsep, filosopi, tata ruang) dengan tujuan melestarikan unsur-unsur lokal yang telah terbentuk secara empiris oleh sebuah tradisi yang kemudian sedikit atau banyaknya mangalami pembaruan menuju suatu karya yang 
lebih modern atau maju tanpa mengesampingkan nilai-nilai tradisi setempat. Seperti yang dijelaskan oleh Leon Krier bahwa Bangunan adalah sebuah kebudayaan seni yang terdiri dalam pengulangan dari jumlah tipe-tipe yang terbatas dan dalam penyesuaiannya terhadap iklim lokal, material dan adat istiadat.

Menurut Zikri (2012) "pada intinya arsitektur Neo-Vernacular merupakan perpaduan antara bangunan modern dengan bangunan bata pada abad 19". Batu-bata dalam kutipan diatas ditujukan pada pengertian elemen-elemen arsitektur lokal, baik budaya masyarakat maupun bahan-bahan material lokal.

Zikri (2012) juga menjelaskan bahwa Arsitektur Neo-Vernakular, banyak ditemukan bentuk-bentuk yang sangat modern namun dalam penerapannya masih menggunakan konsep lama daerah setempat yang dikemas dalam bentuk yang modern. Arsitektur neo-vernakular ini menunjukkan suatu bentuk yang modern tapi masih memiliki image daerah setempat walaupun material yang digunakan adalah bahan modern seperti kaca dan logam. Dalam arsitektur neo-vernakular, ide bentuk-bentuk diambil dari vernakular aslinya yang dikembangkan dalam bentuk modern.

\section{Analisis}

Analisis ikonografis merupakan pokok bahasan sekunder atau konvensional, dengan menghubungkan dunia gambar, cerita, dan alegori atau lambang-lambang yang teridentifikasi sebelumnya. Dalam tahapan kedua ini untuk mengidentifikasi makna sekunder yang dihubungkan dengan tema dan konsep. Oleh karena itu, dibutuhkan pengamatan dengan melihat hubungan bentuk-bentuk tema serta konsepnya dalam pengalaman praktis. Selain itu, juga diperlukan kebiasaan pengalaman mengamati hubungan konsep dan tema dari karya.

Identifikasi pertama dari arsitektur dan interior MRSB ini adalah material yang digunakan dominan menggunakan kayu dan hampir tidak memiliki kaca, yang ada hanyalah lubang-lubang sikurlasi yang terdapat pada ukiran-ukiran pada dinding masjid, desain seperti ini umum digunakan pada arsitektur rumah dengan gaya tradisional di Minangkabau. Hal ini menunjukkan bahwa masjid ini mengusung konsep ramah lingkungan dengan memanfaatkan alam semaksimal mungkin, terbukti juga dengan ruangan masjid ini yang tidak menggunakan pendingin ruangan seperti Air Conditioner (AC). Namun jika dilihat pada bagian interior ruang tampak hal yang sangat berbeda, tema yang paling menonjol dihadirkan pada bagian interior ini adalah tema modern futuristic. Hal ini terlihat dari bentuk dan material bahan yang digunakan yaitu material marmer, alumunium, garnit, dll. Jadi pada dasarnya rancangan arsitektur dan interior ini mencoba menggabungkan beberapa konsep yaitu tradisional dan modern.

Menerapkan sistem ramah lingkungan dan modern tetapi tidak bisa lepas dari unsur tradisional yang menandakan identitas bangunan atau saat ini lebih populer disebut dengan istilah Neo Vernakular seperti yang sudah dijelaskan pada pembahasan deskripsi pra ikonografi sebelumnya. Hal ini mengarahkan penulis untuk berasumsi bahwa bangunan masjid ini berusaha menunjukkan sebuah kekuasaan dari unsur kedaerahan yang kuat, tetapi tetap dapat beradaptasi dengan perkembangan zaman. Jadi, bangunan ini 
merupakan upaya kompromi dari dua buah gaya dan ternyata bisa dipertemukan dan menghasilkan sebuah bentuk baru.

Bentuk baru yang dihadirkan pada bangunan arsitektur masjid ini merupakan inovasi dari adanya perkembangan zaman yang kuat akan teknologi dan pikiran masyarakat yang lebih terbuka, namun dengan tidak mengabaikan hakekat dari kekuatan budaya lingkungan setempat. Hal ini menunjukkan suatu perbedaan dapat menjadi satu dengan adanya kompromi. Hal ini juga sesuai dengan semboyan orang Minang yang sering digunakan ketika rapat yaitu "musyawarah dan mufakat".

Sesuai dengan yang diungkapkan Nasbahry Couto bangunan Rumah gadang merupakan tempat bermusyawarah dan bermufakat. Begitu pula dengan yang dijelaskan oleh Jeffry Hadler (2010) dalam Nasbahry Couto bahwa orang minang lebih mengutamakan "bermusyawarah-mufakat" dari pada "berdebat". Pada dasarnya masyarakat Minangkabau lebih suka menyatukan pendapat untuk mencapai kesepakatan bersama. Jadi, dapat diasumsikan bawa kompromi juga dilakukan untuk mendesain arsitektur dan interior MRSB ini sehingga terciptalah bentuk baru yang lebih inovatif.

\section{Interpretasi Ikonologis}

Deinterpretasi Ikonologis merupakan pengungkapan makna intrinsik atau isi, dengan menyusun nilai "simbolis" dari intuisi sintesis dan sejarah kebudayaan yang terjadi dalam lingkup karya seni yakni; arsitektur masjid, setelah melalui pemahaman lewat deskripsi praikonografi dan analisis ikonografi, dalam tahap ini dibutuhkan kemampuan mental yang disebut dengan intuisi sintesis menyangkut tendensi.

Misi kompromi "musyawarah dan mufakat" yang dicoba diangkat pada bangunan arsitektur MRSB ini mungkin merupakan kegelisahan masyarakat selama ini. Belakangan ini umat Islam sendiri sering mengkotak-kotakkan diri, saling membagi-bagi kelompok dan merasa selalu paling benar dan tidak mau mengalah. Sebagaimana yang sudah banyak diketahui oleh masyarakat luas bahwa terdapat banyak paham-paham dan sekte yang terdapat di Sumatera Barat ini, mulai dari Na'sabandiyah, Moga, Jami'atul Islamiah, AKI, dan lain-lain, yang sering kali berbeda pendapat dan tak jarang menimbulkan perdebatan yang panjang. Tidak ada yang salah ataupun dinyatakan sesat dalam aliran ini, selama ia masih menyembah Allah SWT dan berpegangan kepada $A L-Q u r$ 'an dan Hadist nabi, namun selalu saja banyak dari umat islam yang tidak bisa satu suara dan berkompromi yang tak kadang jadi memandang rendah satu sama lain. Hal ini sangat disayangkan sekali, karena masyarakat Minangkabau di Sumatera Barat yang kental akan nilai-nilai agama Islam, malah saling terpecah-belah.

Banyak aliran tersbut juga memacu adanya aliran-aliran baru yang memang dinyatakan sesat, adapun data tentang aliran sesat tersebut terangkum dalam (Hidayatullah.com:2012) yang mengatakan sebagai berikut; Ketua DPW Muhammadiyah Sumatera Barat, Darlis Ilyas menyatakan aliran sesat kian banyak di Sumatera Barat, Sementara Badan Koordinasi Pengawas Aliran Kepercayaan Masyarakat (Bakor Pakem) mencatat sekitar 25 aliran yang terdapat di Sumatera Barat ini, tetapi yang tidak tercatat atau belum terpantau masih cukup banyak lagi. Darlis mengatakan bahwa "Kita ini bagaikan kain panjang yang dilipat rapi, tetapi di dalamnya ragi kain panjang itu sudah 
habis dimakan ngegat. Artinya, kita perlu benahi individu muslim itu sehingga tidak ada lagi kemaksiatan dan kebejatan moral yang dilakukan anak kemenakan kita”.

Sedangkan Ketua MUI tahun 2012 bidang Fatwa Gusrizal Gazahar menyebutkan, masuknya aliran sesat di tengah kehidupan masyarakat, seperti Aliran Keagungan Illah (AKI) di Bukittinggi yang beranjak dari pluralisme agama, ada pula aliran Baha ' $i$, aliran Jemaah Islamiyah yang sudah ditetapkan Bakor Pakem sebagai aliran sesat, LDII dan lainnya.

Dari adanya data tentang beberapa aliran tersebut, terjadi kegelisahan pada umat Islam di Minangkabau sendiri. Salah satu wujud kegelisahan itu mungkin dapat tercermin dari munculnya MRSB ini. Masjid ini dianggap merupakan upaya untuk memberantas fenomena ban- yaknya aliran di Sumatera Barat, masjid ini bisa menjadi solusi dari perbedaan-perbedaan antara sesama umat muslim itu sendiri. Sebagaimana yang dijelaskan oleh Sayuti (Hidayatullah.com) bahwa masjid ini terinspirasi dari kain untuk mengangkat batu hajar aswad yang dibawa oleh beberapa suku yang memegang ujung kain tersebut. adapun cerita tentang batu Hajar Aswad di Makkah tersebut menunjukkan pertikaian sesama muslim yaitu empat kabilah suku Quraisy yang saling berebut untuk memindahkan batu Hajar Aswad ke tempat semula setelah renovasi Ka’bah. Pada akhirnya Nabi Muhammad SAW memutuskan untuk memberikan jalan tengah dengan cara mengangkat batu Hajar Aswad menggunakan selembar kain persegi empat, sehingga dapat diusung bersama oleh perwakilan dari setiap kabilah dengan memegang masingmasing sudut kain tersebut. Hal inilah yang menjadi dasar dari penggunaan bentuk bentangan kain yang seperti tanduk pada bagian atap masjid ini.

Pada uraian di atas menunjukkan bahwa Islam itu pada dasarnya adalah satu selama pegangannya adalah Al-Qur'an dan Hadist maka dia adalah Islam. Dan sudah seharusnya umat Islam bersatu untuk meramaikan satu masjid, bukan malah terpecah belah dengan membentuk masjid masing-masing dan membuat aturan masing-masing. Karena dengan bersatu masyarakat Sumatera Barat akan mampu mengangkat kembali batang tarandam, bangkit dari keterpu- rukan terhadap bencana yang selama ini terjadi, ambillah pelajaran dan hikmahnya.

Dari uraian di atas masjid ini merupakan tempat untuk menampung semua kegiatan keIslaman dan kemasyarakatan di Sumatera Barat ini. Dengan desain yang megah dan luas diharapkan dapat memancing umat Islam untuk beramai-ramai ke masjid ini baik untuk bersilaturahmi dan melakukan kegiatan social lainnya sebagai sesama muslim.

\section{Kesimpulan}

Penelitian dilakukan pada masjid Raya Sumatera Barat (MRSB) ini menghasilkan identifikasi penanda visual pada bagian-bagian pada MRSB tersebut menunjukkan bahwa arsitektur menghadirkan bentuk-bentuk tradisional rumah gadang, dan sudah mengalami bentuk perpaduan gaya modern sehingga tidak menghasilkan bentuk murni tradisional, sedangkan pada interior bangunan didominasi oleh bentuk-bentuk modern. Hal ini menunjukkan bahwa masjid ini menggunakan prinsip penataan dua konsep yaitu tradisional dan modern atau dikenal dengan tipe Neo Vernakular. 
Makna konvensional tentang tema dan konsep yang membangun karakter dari desain interior dan Arsitektur MRSB ini memakai konsep berdasarkan filosofi masyarakat Minangkabau tentang "musyawarah dan mufakat". Misi kompromi pada istilah di atas menjadi landasan akan terjadinya penggabungan beberapa gaya di dalam desain MRSB ini. Di satu sisi masyarakat Minangkabau sudah melewati perkembangan zaman dengan keterbukaan pemikiran, di sisi lain mereka sangat menghargai dan menjunjung tinggi adat dan hasil kebudayaan yang selama ini berada di dekat mereka, maka dari itu terciptalah bentuk baru dari kedua sisi pemikiran tersebut.

Makna intrinsik pada masjid ini antara lain untuk mewujudkan misi perdamaian di Sumatera Barat. Hal ini diasumsikan tercetus dari adanya fenomena di Sumatera Barat yang pernah ramai akan banyaknya aliran terhadap agama Islam. Hal ini terkadang menyebabkan perpecahan di antara umat Islam sendiri. Jadi pembangunan masjid merupakan upaya untuk mewujudkan Islam yang damai di Sumatera Barat. Dengan desain yang megah dan luas diharapkan dapat memancing umat Islam untuk beramairamai ke masjid ini baik untuk bersilaturahmi dan melakukan kegiatan sosial lainnya sebagai sesama muslim. Upaya penyatuan umat muslim ini didasari dari hadis yang mengatakan bahwa akan ada berbagai macam aliran terhadap Islam, namun hanya aka nada satu yang diterima oleh Allah SWT. Dari sinilah orang-orang selalu bertanya-tanya akan aliran islam yang diterima, namun sebenarnya islam yang diridoi oleh Allah bukanlah islam yang satu yaitu yang berpedoman kepada Al-Qur'an dan hadist nabi. Hal ini menunjukkan bahwa kita berada pada era baru, yaitu era tanpa batas, tidak ada batasan antara gaya satu dan lainnya, kenapa harus dipisahkan-pisahkan jika dengan bersatu lebih tampak harmonis.

\section{KEPUSTAKAAN}

Kaelan. 2005. Metode Penelitian Kualitatif Bidang Filsafat, Budaya, Sosial, Semiotika, Sastra, Hukum, dan Seni. Yogyakarta: Paradigma.

Panofsky, Erwin. 1939. Studies in Iconology: Humanistic Themes in the Ars o the Renaissance. Newyork: Oxford Up. (3-31). 1995. Meaning of The Visual Arts. Newyork: Doubleday Anhor Books.

Rochym, abdul. 1995. Mesjid Dalam Karya Arsitektur Nasional Indonesia. Bandung: Offset Angkasa.

Rony, Aswil, dkk. 1999. Alat Ibadah Muslim Koleksi Museum Adhityawarma. Padang: Bagian Proyek Pembinaan Permuseiman Sumatera Barat.

Situmorang, Oloan. 1988. Seni Rupa Islam: Pertumbuhan dan Perkembangannya. Bandung: Angkasa.

Rony. 2013. Ikonografi Arsitektur dan Interior Masjid Kristal Khadija Yogyakarta. dalam society's Arts volume 14 no 2 oktober 2014: 121-134.

https://www.scribd.com/doc/46656529/Budaya-Matrilineal-Masyarakat Minangkabaupada- Arsitektur-Minangkabau

http://ahluldesigners.blogspot.com/2012/08/arsitektur--vernakulara.html

http://visualheritageblog.blogspot.com/2010/1/morfologi-bentuk-bangunan-tradisi.html http://www.nahimunkar.com/sumatera-barat-dibanjiri-aliran-sesat/

http://ceritasihijaudarikebunbungamatahari.blogspot.com/2012_08_01_archive.html www.aber.ac.uk.diakses 20 Agustus 2008. 